\title{
Transnationalism in Question ${ }^{1}$
}

\author{
Roger Waldinger and David Fitzgerald \\ University of California, Los Angeles
}

\begin{abstract}
This article seeks to critically engage the new literature on immigrant transnationalism. Connectivity between source and destination points is an inherent aspect of migrations, but migration networks generate a multiplicity of "imagined communities," organized along different, often conflicting principles. Consequently, what immigration scholars describe as transnationalism is usually its opposite: highly particularistic attachments antithetical to those by-products of globalization denoted by the concept of "transnational civil society." Moreover, migrants do not make their communities alone: states and state politics shape the options for migrant and ethnic trans-state social action. International migrants and their descendants do repeatedly engage in concerted action across state boundaries, but the use, form, and mobilization of the connections linking "here" and "there" are contingent outcomes subject to multiple political constraints.
\end{abstract}

At the turn of the 21st century, globalization is the order of the day. With international migration bringing the alien "other" from third world to first, and worldwide trade and communications amplifying the feedbacks traveling in the opposite direction, the view that nation-state and society normally converge has waned. Instead, social scientists are looking for new ways to think about the connections between "here" and "there," as evidenced by the interest in the many things called transnational. Those studying international migration evince particular excitement. Observing that migration produces a plethora of connections spanning home and host societies, these scholars proclaim the emergence of transnational communities.

\footnotetext{
${ }^{1}$ Grateful acknowledgments are owed to Rogers Brubaker, Susan Eckstein, Adrian Favell, David Lopez, John Mollenkopf, Andreas Wimmer, and Maurice Zeitlin for their critical and deeply helpful comments on earlier drafts of this article. Direct correspondence to Roger Waldinger, Department of Sociology, University of California, 264 Haines Hall, Box 951551, Los Angeles, California 90095-1551. E-mail: waldinge@soc.ucla.edu
}

(C) 2004 by The University of Chicago. All rights reserved. 0002-9602/2004/10905-0005\$10.00 
American Journal of Sociology

Connectivity between source and destination points is an inherent aspect of the migration phenomenon-no surprise given the social networks that channel the process. However, those networks generate, not one, but a multiplicity of imagined communities (Anderson 1983), organized along different, often conflicting principles, whether related to the scale of aggregation (local vs. national) or to the opposing visions of the community in question. On occasion, these imagined communities conform to the root meaning of transnational—extending beyond loyalties that connect to any specific place of origin or ethnic or national group. Yet what immigration scholars describe as transnationalism is usually its opposite: highly particularistic attachments antithetical to those by-products of globalization denoted by the concept of "transnational civil society" and its related manifestations (Florini 2000).

Moreover, migrants do not make their communities alone. Intellectual fashions notwithstanding, states and the politics conducted within their borders fundamentally shape the options for migrant and ethnic transstate social action.

First, states seek to control movement across territorial boundariesexit as well as entry. Therefore, defining transnationalism in terms of the "regular and sustained" cross-border activities of individuals, as do Portes and his associates (Portes, Guarnizo, and Landolt 1999), takes for granted what needs to be explained. Doing so also makes freedom of movement the point of departure, as if this were not a world divided by states, many of them expelling their undesirable residents or closing their doors to foreigners.

Second, state controls operate at internal as well as external levels, seeking to regulate membership in the national collectivity, as well as movement across territorial borders. That both boundaries prove leaky is the rule, not the exception (Krasner 1995). More relevant is the variability in the degree to which internal and external boundaries are institutionalized and the means and intensity by which states police them. Together, these factors condition the ability of migrants living "here" to act in ways that yield leverage "there."

Third, civil society actors in both host and destination countries raise questions regarding the allegiance and political bona fides of persons whose social identities are largely framed by their connections to two states. The terms of national belonging are almost always the subject of conflict; variations in political culture ensure that they also differ from one nation-state to the other.

Fourth, the relationship among states affects the scope for multiple versus exclusive national loyalties. The security/solidarity nexus waxes and wanes with the degree of interstate tension. Dual loyalty becomes a particularly intense issue when belligerency develops between host and 
sending countries. Thus, while international migrants and their descendants recurrently engage in concerted action across state boundaries, the use, form, and mobilization of the connections linking here and there are contingent outcomes subject to multiple political constraints.

We develop this argument in the following pages. Engaging the existing literature, we argue that conventional social science overlaps with folk understandings that nation-states normally contain societies (as implied by the concept of "American society"), which is why the appearance of foreigners and their foreign attachments are viewed as anomalies expected to disappear. Our point of departure is utterly different. Networks of people, information, and goods regularly span the boundaries of the state, leading international migration to consistently recur. Since a container model of society enjoys widespread legitimacy, the arrival of foreigners persistently sparks state efforts to bound the societies they enclose, as well as civil society attempts to reinforce the boundaries of the national community that international migration threatens to disrupt. Consequently, the standard depiction of assimilation and transnationalism as competing theoretical perspectives or analytic concepts is misleading. While the sociological dictionary defines "assimilation" as the decline of an ethnic difference (Alba and Nee 2003), assimilation is also the making of difference between national peoples. As ideology of the nation-state society, the sociology of assimilation necessarily obscures coercive efforts to build a nation-state society by excluding outsiders-via control of external borders - and to distinguish between members and unacceptable residents of the territory - through regulation of the internal boundaries leading to citizenship and legal residence. Likewise, for transnationalism, the relevant forms of social action do not transcend difference but rather are directed entirely toward specific places or groups. In the end, assimilation and transnationalism are each as particularistic as the other. The collision between these processes defines the phenomenon of interest to us here.

Rejecting the conventional views, we outline an alternative approach that emphasizes the interactions of migrants with states and civil society actors in both sending and receiving countries. We apply that approach to show how sustained comparisons across time and place illuminate the sources of variation in migrant trans-state politics, a matter obscured by the current literature, preoccupied with the single case of the United States and a dehistoricized fixation on the contemporary period.

\section{THE CAREER OF A CONCEPT}

The concept of "immigrant transnationalism" entered the literature through the work of anthropologists Glick-Schiller, Basch, and Szanton- 
American Journal of Sociology

Blanc (1992), who argued that the emergence of transnational social fields linking particular sending and destination countries represented a break with the past. Contrary to historical patterns and received social science notions, neither settlement nor the severing of home country ties was inevitable. In the contemporary age of migration, rather, "transmigrants . . . maintain, build, and reinforce multiple linkages with their countries of origins" (Glick-Schiller, Basch, and Szanton-Blanc 1995, p. 52), thereby expanding the range of "home" to encompass both here and there. Such a fundamental change required entirely new concepts: "transnationalism" identified the social connections between receiving and sending countries; "transmigrants" denoted the people who forged and kept those ties alive (Glick-Schiller et al. 1992).

Though the new idea quickly caught on, conceptual disagreements soon emerged. One view emphasized transnationalism, a complex but fundamentally closed set of relationships so encompassing as to virtually erase the distinction between here and there. The influential formulation developed by Portes and his associates exemplifies this stance: for them, the concept of transnationalism is delimited "to occupations and activities that require regular and sustained social contact over time across national borders for their implementation" (Portes et al. 1999). A different approach, emphasizing transnational practices, as opposed to a transnational condition of being, replaces the fine lines associated with transnationalism with a continuum: here, the regular, sustained trans-state practices underscored by Portes and his associates shade off into something more erratic and less intense (Levitt 2001b).

Further difficulties arose in conceptualizing the cross-border activities that interact with migrants' transnational engagements. One formulation contrasts the "transnationalism from above" of corporations and states with the "transnationalism from below" of international migrants (Smith and Guarnizo 1998). The severing of enterprise from its original, national base exemplifies the core of the transnational concept. Describing the actions of states as transnational, however, deprives the concept of analytic leverage, as it is meant to distinguish cross-border, nonstate actors from states and to show how the two constrain and shape one another. An alternative, identifying the linkage between sending states and their members on foreign soil as exemplifying the "deterritorialized nation-state," stretches the definition of the state beyond meaning. States only legitimately possess the power of coercion within their own borders, and consular activities abroad depend on the acquiescence of hosts.

Additional conceptual permutations will surely arise. However, no disagreement exists regarding the relationship between immigrant transnationalism and receiving states, largely because the matter has not been 
raised. ${ }^{2}$ Aware that immigrant dual loyalties may produce allergic reactions among their hosts, scholars have sought to calm such fears, noting that home country allegiances rarely persist to the second generation, in which event transnational activities should be accepted, as they "can actually facilitate successful adaptation" (Portes 1999, p. 472). While the advice may be sensible, the absence of any concerted effort to analyze the relationship between immigrant transnationalism and receiving states and civil society actors is a fundamental omission.

The Politics of Here and There

With sympathizers, if not adherents, of the transnationalist view at the helm of three scholarly journals (Diaspora, Identities, and Global Networks); an international center on transnational communities based at Oxford University; and a legion of supportive books, articles, and dissertations pouring out across the social sciences, the transnationalist moment would seem to be now. ${ }^{3}$ One hesitates to be left standing in the station when the train is so obviously departing. Still, perhaps there is time for a spirited warning before everyone gets on board.

We agree that this new literature has drawn scholars' attention to a salient aspect of international migration. Alas, it has not delivered on its promise. International phenomena can be distinguished from those that are transnational. As argued by international relations scholars since the 1960s, the former pertains to relations between states, the latter to institutions extending beyond and even encompassing states. But one simply has to invoke any of the many transnational institutions-whether the market, the Catholic Church, or the more recent networks of human rights activists - to see that transnational phenomena, properly speaking, have at best variable relevance to the migration cases at hand. It would be otherwise were we talking about the last great age of migration, when no small proportion of the international movers understood themselves to be "workers of the world." But at the turn of the 21st century, the best approximation of transnationalism of this sort is to be found among the "transnational capitalist class" (Sklair 2001), still bound to its country of origin, but increasingly oriented toward the elimination of economic na-

\footnotetext{
${ }^{2}$ Smith and Guarnizo provide the exception that proves the rule. While noting that "agents of 'receiving states' remain relevant actors" (1998, p. 9), they only devote a paragraph to the matter. We have found only one scholar who pursues the matter further (Ostergaard-Nielsen 2001a, 2001b) and none who focuses on the United States, otherwise the main topic of attention.

${ }^{3}$ For the Oxford program, funded by the U.K. Economic and Social Research Council from 1997-2003, see http://www.transcomm.ox.ac.uk, including a list of 62 working papers and a Routledge book series, with 11 titles, as of this writing.
} 
American Journal of Sociology

tionalism. By contrast, the political behavior described by scholars of contemporary immigrant transnationalism is altogether different, involving long-distance, trans-state affiliations of a particularist sort-a form of social action entirely distinguishable from transnationalism in any of its incarnations.

The matter could be resolved easily if it were just a matter of nomenclature. Unfortunately, the literature conflates aspects of the phenomena intrinsically related to migration across nation-states with those that emerge under internal and international migration. Many of the most influential studies of immigrant transnationalism (Rouse 1995; R. Smith 2002; Levitt 2001a) actually examine the trans-state connections between particular places here and there-localistic ties reappearing in similar form just about everywhere that long-distance migration occurs. For example, Midwestern migrants to California in the 1920s created state-based associations that picnicked, through the 1960s, in the same Los Angeles public parks where Guatemalan and Mexican associations gather today. Similarly, the governors of Iowa made the trek to California to campaign among their "paisanos" long before the governors of the Mexican states of Zacatecas and Jalisco thought to do the same. ${ }^{4}$ Such affiliations and organizations based on distant hometowns result from the interaction between natives and strangers and not necessarily the encounter between nationals and foreigners. Thus, discovering connections between villages or communities here and there hardly qualifies as transnational, as the same relationship reoccurs within almost any domestic or international migration.

To the extent that migrant bilocalism is a product of the migration experience, it represents a break with the experience of the stay-at-homes. Therefore, it also serves as a vehicle for innovation in the interaction between the migrants and their connections still at home, making the use of holistic metaphors-like transnational community or village-inappropriate. Bilocalism can be a stage in the development of a broader set of identities, but not necessarily; often it works in the opposite direction, as the hometown association competes with other forms of organization that emphasize politics or ideology over affective ties. To survive, hometown associations have to unite right and left, believers and secularists, proletarians and entrepreneurs-which is why their antipolitical bias is often so strong. Those conflicts also highlight a history of consistent contention over the precise nature of the homeland community to which loyalty is owed, suggesting that the literature's conceptualization of transnationalism is largely reification.

${ }^{4}$ See our manuscript, "Immigrant 'Transnationalism' Reconsidered," at http://repositories.cdlib.org/uclasoc/ for more on this topic. 
Transnationalism in Question

Trans-state Migrant Social Action

If the concept of transnationalism cannot cover the many discrete, opposing phenomena to which its scholarly advocates would have it refer, the proliferation of ties extending beyond the territory that states seek to enclose does merit close attention. These connections only violate those tenets of nationalist ideology that define normality as the conditions under which a nation is separate and distinct from the world found on its edges (Wimmer and Glick-Schiller 2002). While nationalist ideology and social science theory on the topic overlap-as unintentionally implied by Guarnizo et al. (2003, p. 6), who position themselves against a "theoretical perspective" that "expects immigrants to have a single identity, national allegiance, and representation in one national polity"-the analyst's job is to take critical distance from the native theory of the world, not to use it as the point of departure.

As noted, networks of information, goods, and services regularly extend beyond the limits of state institutions. The mass international migrations of the turn of the 20th and 21st centuries have entailed one-time return migration, repeat migration, and circular migration, as well as migration for settlement. Such flows leave large numbers of persons moving back and forth, not certain where to settle, let alone how much importance to place on the connections to here versus there. Gradually, the networks that breach the nation-state society pull migrants away from home environments, encouraging settlement. The short- to medium-term horizons, however, may look different. As long as migration increases, so does the prevalence of cross-border ties, a factor affecting the dispositions of veteran migrants and the opportunities they confront.

Since our interests lie in the constitutive aspects of movement across borders, we emphasize that states make migrations international by bounding territories and defining the nations they seek to enfold (Zolberg 1999). Population movement across state boundaries is inherently a political matter: it threatens to sever the alignment of territory, political institutions, and society that states try so hard to create. From the standpoint of the receiving states, international migrants are aliens, not just strangers. Their arrival makes the relationship between nationals and foreigners a matter of domestic as well as foreign policy. A similar situation holds on the sending side, as international migration represents a twofold threat to the sending state's power. Exit weakens the home state's ability to cage and penetrate its population. Access to another territory and its greater economic and ideological resources gives migrants newfound leverage to effect change at home.

Migration represents both threat and opportunity for sending and receiving states that negotiate bilateral agreements like the bracero program, 
American Journal of Sociology

which imported Mexicans for work in the United States, or postwar European "guest worker" programs Wanting labor control and temporary migration without settlement, both sides collude to stifle independent migrant action, which is why sending states can extend surveillance and policing to the territory of the receiving state with the latter's assent. However, even officially invited guests come to stay. The same naturally applies to migrations that take a more autonomous form. Once embedded, and at least partially freed from state control, migrant networks create the potential for forms of trans-state social action, to which others in host and home contexts then respond.

As states are membership organizations, with formal citizenship rules conditioning the potential for participation in host and home contexts (Brubaker 1992), migrant membership becomes an object of contestation on both ends of the chain. Ethnic or migrant cross-border social action is therefore a "matter of state," but societal influences invariably come into play, especially since the spheres of ethnocultural and formal membership only rarely coincide. National identity is relational, defined in contrast to alien and external states and people. However, international migrations take aliens from outside the state's territory and bring them inside, either directly, as in the receiving states, or indirectly, via the networks that link persons in the home territory to associates in foreign places, as in the sending states. Alien persons or persons with alien connections are subject to suspicion. Their affiliations with foreign people and places put questions of belonging on the political agenda, leaving the legitimacy of migrant or ethnic trans-state social action under threat.

Loyalty to more than one state has historically elicited negative public reaction. In receiving countries, foreign origins or attachments impede acceptance and generate persistent perceptions of disloyalty. Even in the United States, where a civic conception of nationhood prevails, dominant group members view African-, Asian-, Hispanic-, and Jewish-Americans as "open to divided loyalties and therefore less patriotic than "unhyphenated' Americans" (Smith 1994, p. 9). Though circumscribing, not preventing, homeland-oriented activities, such suspicions show that crossstate migrant or ethnic membership is not an individual attribute, but rather an accomplishment effected through interaction with myriad actors.

While the social organization of international migration variably sustains involvements both here and there, neither membership nor the means of maintaining ties on both sides is a matter for migrants to decide on their own. International migrants may "see themselves as transnational, as persons with two homelands," as noted approvingly by Glick-Schiller and Fouron (1990, p. 341). That view, however, is hardly binding on anyone else, as evidenced by the past century's record of producing refugees without home or host, let alone persons without a state. States not 
only confer a migrant's rights to life in the territory; they regulate contacts across borders. In totalitarian states, where emigration is tantamount to betrayal, the regular and sustained contacts between source and destination societies that supposedly distinguish transnationals from immigrants are not just out of the question, but imperil sending-country residents whom the transnationals try to contact or help. Even liberal states control the travel of those over whom they have authority, limiting the scope for travel by immigrants whose home country stands in hostile relations to their host.

The relationship among states also affects the conditions under which international migrants and their descendants can pursue homeland interests. In general, a peaceful world encourages states to relax the security/ solidarity nexus. International tension, let alone belligerence, provides the motivation to tighten up on those whose loyalties extend abroad (Armstrong 1976). The specifics of the relationship between particular sending and receiving states matter even more. Homeland loyalties extending to allies or neutrals can be tolerated easily; those that link to less friendly, possibly hostile states are more likely to be suspect. Likewise, power differentials between sending and receiving states count. Migrant origins in a more powerful source raise questions about bona fides on both sides, as receiving and sending states have an interest in transforming migrant trans-state social actors into their agents.

While states have often wrongly suspected international migrants of dual loyalty, they have not always erred: immigrants have occasionally served as instruments of some other authority here or there. That migrant cross-border social actors are more likely to be opponents than servants of the home state does not necessarily please receiving states concerned with international stability, the undermining of which is precisely what migrant long-distance nationalism can sometimes entail (Anderson 1998; Weiner 1993). Moreover, migratory and ethnic connections crossing state borders also provide the vehicle for diffusing conflicts from home country to host, adding international tensions to social antagonisms of mainly domestic origin. And alongside the benign activities emphasized by the literature, one has to note the more noxious record of those long-distance migrant and ethnic nationalists who have repeatedly used the most unsavory means. ${ }^{5}$

That migrant and ethnic social action should take benevolent and malignant forms is no accident. They both inherently derive from the stateness of the receiving environment, which constrains the tentacles of the sending state, creating degrees of freedom unknown before migration. Unfortunately, the scholars of immigrant transnationalism have been too

${ }^{5}$ See Hockenos (2003) for the pernicious consequences of "exile patriotism." 
American Journal of Sociology

fond of the phenomenon they study to notice these unpleasant aspects. Were it otherwise, they would surely not have veered so far toward celebrating the phenomenon they purported to analyze, depicting transnationalism as subversive and transnationals as grassroots actors challenging the hegemony of states and global capitalism "from below" (Rogers, Cohen, and Vertovec 2001). Alas, reality bites back, since not all readers conclude that multiple national loyalties are a good thing. The purported prevalence of transnationalism gives those already thinking that the national community is under threat additional reason to worry and insist that boundaries get rolled back (Huntington 1997). Understandably, advocates of ethnic trans-state social action find such allergic responses displeasing. However, those reactions fully belong to the phenomenon, to be ignored only at the price of implicating oneself in a subject of which one should uniquely be a student. By limiting the transnational field of study to the generally pacific activities of groups whose cause may appear noble or innocuous, scholars obscure the conditions that foster or limit the full range of long-distance nationalisms in both receiving and sending contexts.

\section{Beyond the Here and Now}

To reprise, we are not rejecting transnationalism to revert to the so-called orthodox theories with which this literature is actually twinned. On the contrary, the phenomenon deserves serious scholarly attention, but only when redefined as the collision of the social organization of migration, and its state-spanning results, with reactive efforts by state and civil society actors to produce state-society alignment. These interactions involve a multiplicity of actors coming together in a broad range of combinations and a variety of circumstances.

However, the very limited sample of cases thus far considered, not the nature of the data collected, makes it hard to assess the range of possibilities. In theory, the literature's reliance on case studies is irrelevant. The investigator can draw on such strategies as the negative, deviant, or critical case study to build in information from a much larger sample and thereby draw reliable inferences based on intensive study of just one case. Similarly, results from sample surveys are generalizable to the populations from which the surveys are drawn, but no further, unless the unstudied populations are instances of the same or similar case. The recent article by Guarnizo et al. (2003) surely represents an advance in its systematic comparison of a set of cross-border political activities among three immigrant populations. Yet contemporary international migrations to the United States from small, weak countries on the U.S. periphery capture but a limited portion of the phenomenon in question. To illuminate its 
full range and gain purchase on the broader set of variables in play, one needs to extend the range of cases. This is the task we now pursue, though in purely illustrative fashion, given this article's limited scope. ${ }^{6}$

Temporal comparisons.-From the outset, the literature on immigrant transnationalism insisted that the contemporary experience represented a decisive break with the past. Historians immediately dissented, but the argument for discontinuity proved hard to abandon. For example, Portes and his associates (1999) first argued that the case for studying transnationalism rested on the very novelty of the phenomenon itself, but later, noting the historical precedents, they sought to rescue the concept by invoking the "fallacy of adumbration." Conceding that the phenomenon was not new, they found that transnationalism illuminated previously unnoticed parallels linking "contemporary events with similar ones in the past" (Portes 2001, p. 184), and therefore they concluded that the concept yielded significant added value (Portes, Haller, and Guarnizo 2002).

While agreeing that the phenomenon can be old hat, even as the concept does "new analytical work" (R. Smith 2003, pp. 722-23), scholars of immigrant transnationalism (Levitt 2001a; Guarnizo 2001; R. Smith 2002; Foner 2000; Glick-Schiller 1999) still insist that the present significantly diverges from the past in the following ways:

1. technological change has reduced the costs and time entailed in communication and travel;

2. the shift from melting pot to multiculturalism has legitimated the expression of and organization around home-country loyalties;

3. the nationalization of home-country societies has increased the salience of the national identities with which immigrants arrived; and

4. the advent of a new international human rights regime (labeled "postnationalism") has diminished the difference between nationals and foreigners by circumscribing the power of receiving states.

Few have taken issue with these conclusions, with Morawska's the most notable dissent. Noting that nothing is ever quite the same, she argued that the "lifeworlds and diaspora politics of turn-of-the-century immigrants share many of the supposedly novel features of present-day transnationalism" (2001, p. 178).

These well-taken criticisms still leave fundamental difficulties unsaid, beginning with the insistence on a qualitative distinction between an illdefined and unperiodized now and then. Claiming discontinuity, the students of immigrant transnationalism have effectively dehistoricized the present. They have also reproduced the familiar antinomies of social sci-

${ }^{6}$ For full referencing of the historical and comparative material, as well as extended discussion, see our web-posted paper, "Immigrant 'Transnationalism,' Reconsidered." 
American Journal of Sociology

ence, most notably that of a closed past and open present (Amselle 2002), which is why the students of globalization, immigrant transnationalism, and transnational relations all end up with the same "discovery" - that it happened before and in surprisingly similar ways.

More important, the students of immigrant transnationalism have not confronted the alternative hypothesis advanced by Arendt (1951) a half century ago. Due to the global spread of the state system and the nationstate society, the condition of having no home-not two homes-is what distinguishes now from then. Since World War I, states would rather "lose . . . citizens than harbor people with different views" (Arendt [1951] 1996, p. 278). As the world has been completely organized into states, persons who lose a polity find "themselves thrown out of the family of nations altogether" (p. 294). The Arendtian and turn-of-the-21st century worlds may not be identical. However, the presence of 20 million refugees worldwide, large populations of illegal immigrants with limited rights even in liberal democracies, and continued resistance to claims for asylum (UNHCR 2000), suggest far greater resemblance than scholars of immigrant transnationalism maintain. In the long view, the rise of massive state apparatuses controlling population movements between states represents the most striking development.

Moreover, contingency should be put back into the flow of history, implying that the current state of affairs is not inevitable, but rather is subject to unpredictable pressures of the sort that burst earlier eras of global interconnection asunder. The technological determinism asserted by the proponents of immigrant transnationalism deserves second thought. Earlier, the simple letter knitted together transoceanic migration networks with remarkable effectiveness. Moreover, a political environment supportive of immigrant and ethnic long-distance nationalism should hardly be taken for granted. If responsibility for modestly relaxing the distinction between nationals and foreigners lies with domestic political actors, and not with new international norms or an international human rights regime (Joppke 1998), then domestic actors can also produce movement in the other direction. Likewise, the legitimacy currently accorded expression of homeland loyalties is better understood as a product of the moment, not a permanent feature of advanced democracies. Given that migrants' trans-state particularism may conflict with the liberal universalism of groups supporting immigrant rights, and that migrants remain susceptible to dual loyalty changes associated with restrictive conceptions of the national community, a scaling back is always possible.

Consequently, the analytic task can proceed neither through the construction of categorical oppositions nor through the search for parallels between now and then. Rather, one should focus on temporal variation in the political constellations shaping the environment for trans-state eth- 
nic and migrant social action and on the sources of any such changes. We identify two axes of variation around which structured historical comparisons can be pursued: one relating to a characteristic of the migrants, the second to characteristics of the interstate system.

The migrants. - The trans-state particularism described as immigrant transnationalism presumes migrants, coming from nationalized societies where identity is defined by contrast to alien peoples and lands. However, the presence of trans-state social connections may not imply long-distance nationalism. The peasant migrants of the turn of the 20th century engaged in circular or recurrent migration and clustered in jobs and neighborhoods alongside their fellow hometowners, whom they joined in more formal associations. But as they also came from a set of folk societies not yet nationalized, they lacked the common traits and corporate sense that nation-building processes impart. Consequently, the literature (e.g., Foner 2000, p. 173) engages in anachronism when insisting that persons not yet knowing that they were Italians or Poles, but intensely loyal to this hometown and not its neighbor, were nonetheless the "quintessential transnational(s)."

Abandoning the game of determining who is really what, we find utility in emphasizing the relationship between the prior experience of nationalization and the forms of trans-state social action that migrants pursue in the new setting. Compared to their turn-of-the-20th-century counterparts, the migrants of the turn of the 21st century are generally more likely to come from nationalized societies in which internal differences have been diminished. Consequently, they arrive with loyalties extending considerably beyond the local level, making the national the more likely basis for mobilization and aggregation.

However, some contemporary migrants come from weakly or only partially nationalized societies, yielding greater similarity to the newcomers of the last era of mass migration than usually acknowledged. The closest parallel involves migratory trade diasporas from Africa implanted throughout Europe and North America (Stoller 2002). They fully comply with Portes's strictures that transnationalism entail regular and recurrent trans-state contacts. Among these groupings, however, the national impulse has yet to take root; regional or religious attachments override those of nationality. On the other hand, because many postcolonial states are often arbitrarily assembled collections of multiethnic peoples, the stateseeking nationalisms that powerfully affected the migrants of the turn of the 20th century remain important today.

Interstate relations.- The condition of interstate relations affects the ability to maintain national loyalties of a dualistic type. Advantage flows to state-seeking nationalists in the diaspora when their goals overlap with those of host-country social actors or authorities. The bounds of accept- 
able, trans-state social action are easily crossed, however. Diasporainduced conflict between host- and home-country authorities is often unwelcome, yielding host-country decisions to curtail migrants' political activities oriented toward the homeland.

Though relational-defining whom we are by contrast to those whom we are not - the constraints of national identity are variable. In peacetime, immigrants (and their descendants) can maintain identities that might seem mutually exclusive. The advent of war often forecloses those options. One can try to profess allegiance to two mutually belligerent states, but it is difficult, as no one is more threatening than the detested and feared "other" located within the boundaries of one's own state. Moreover, the popular nature of modern wars threatens to transform immigrants from enemy foreign countries into internal foreign enemies.

Consideration of the experience in the United States shows that war does not yield a single, deterministic effect. World War I prompted the forced assimilation and destruction of German-America. As the total war of the 1941-45 era demanded the mobilization of all Americans, its ideological goals conflicted with the reality of ethnic discrimination, accelerating the integration of the southern and eastern European origin groups. In somewhat similar, though paradoxical fashion, the same international constellation that spelled disaster for the Japanese-Americans benefited Chinese-Americans, who not only saw the (admittedly symbolic) lifting of the Chinese Exclusion Act, but also were allowed to mobilize on behalf of precisely the homeland that America had previously despised. Nonetheless, solidarity with coethnics abroad caused constant suspicion in official circles. When push came to shove, the demands for U.S. national solidarity overrode concerns for ethnic solidarity, as indicated by the behavior of American Jews, whose beleaguered coethnics in Europe begged that their American cousins shake "the earth . . . to its foundations [so that] . . . the world be aroused" (Karski 1944, pp. 327-28), but to no avail.

The ideological nature of international relations rendered immigrants vulnerable on grounds not just of alien origins, but also alien, "unAmerican" ideas. With the Cold War, adherence to communism barred one from naturalization, and deportation was employed to help destroy the left. Though virtually no one's loyalty was then beyond suspicion, groups with a vouchsafed status as enemies of the enemies of the United States had a green light to openly express old world ties and allegiances, as in the case of the so-called "captive nations" behind the Iron Curtain. However, one had to be careful about one's choice of enemies, since former foes sometimes became friends. In the 1950s, American Jews were unhappy about American aid to Germany, not to speak of its rearming and the return of countless ex-Nazis to positions of prominence, but they knew 
enough to keep quiet. In the late 1960s, by contrast, because the campaign to "release" Jews from the Soviet Union positioned American Jews as the enemies of their country's enemy, they could ignore opposition from the highest U.S. political levels without running the risk of raising the dual loyalty flag.

The contemporary era of mass migration belongs to a different world, or so it appeared until just recently. While new technologies may facilitate trans-state ties, they were seen as embedded in a more pacific world order, in which national allegiances have once again been allowed to overlap, as opposed to the mutual exclusivity expected for most of the short 20th century (Hobsbawm 1994). Not all groups are equally lucky in this respect. Immigrants from countries with unfriendly relationships to the United States run the risk of falling into the "enemy alien" trap. That longdistance nationalism in all of its forms (including that of the time-honored ethnic lobby) does not come so easily to Arab-Americans shows that the exception proves the rule: when loyalty is in question, long-distance nationalism is a hazardous game.

Just how the sudden inflection of international tension in the early 21 st century will affect the pursuit of immigrant and ethnic homeland loyalties is anyone's guess, but the lessons of history indicate that perception of external threat builds support for a more restrictive view of the national community. Past experience also shows that the American state has the capacity to monitor, control, and restrict the trans-state social action of international migrants and their descendants. Whether and to what extent that capacity will be activated is a matter to which scholars of immigrant transnationalism will surely want to attend.

International comparisons.-The international dimension of migration is underappreciated by U.S. scholars. Allowing national borders to define the field of study, they have obscured the nation-building and maintaining aspect of responses to international migration by focusing their interest on the variation within their sample of one. Just a modest expansion of the sample highlights dynamics one would not see otherwise.

Extending the focus cross-nationally lets one examine the possible effects of variations in political culture - in this case, national membership rules-and assess whether and how they affect the options for maintaining allegiances here, as well as there. The best vehicle for analysis entails within-group comparisons across different national incorporation systems. As an example, consider the options for maintaining dual loyalties among migrants and their descendants under two sets of ethnocultural systemsnamely, the Jews who moved to the pluralistic system of the United States versus those who settled in the unitary system of France.

Cross-border social action was a salient aspect of the ethnic experience on both sides of the Atlantic, but it took very different forms. The strong 
American Journal of Sociology

form of assimilation à la française made Zionism taboo in official, organized circles up through World War II. However, that same system proved perfectly compatible with a less politicized form of Jewish crossborder ethnic action-the Alliance Israélite Universelle-which transmitted French cultural ideals as well as schools and related services under strictly Jewish auspices to a strictly Jewish clientele. In contrast, organized American Jewry as well as rank-and-file Jews proved highly responsive to Zionism's appeal, before and after the establishment of the state of Israel. While American Jews have since come to compose the classic ethnic lobby, in France the ethnic lobby appears as a foreign import from the United States, making similar activities by their French cousins far more constrained.

Further insight is gained by assessing the implications of differences in political structure, loosely controlling for political culture. Focusing on ethnoculturally plural systems-the United States, Canada, and Australia-highlights the relevance of the former's political fragmentation. The loose coupling of U.S. politics at federal, state, and local levels often contains the politics of long-distance nationalism to local or state levels, without ramifying nationally. Consequently, fragmentation averts the outcome most likely to increase the possibility of a negative ethnocultural reaction based on the premise that "politics stops at the water's edge." On the other hand, the relatively fragmented nature of U.S. federal politics motivates ethnic lobbying, as it does all other forms of interest group politics, none of which would be as potent were the national polity organized as a unitary regime. Thus, even within similarly pluralistic ethnocultural systems, the greater pluralism of the United States' political structure facilitates the legitimate mobilization of immigrant and ethnic trans-state social action.

\section{CONCLUSION}

International migrants usually have good reason to leave home, but once abroad, they are often motivated to sustain a connection to the town, region, or nation left behind. Members of the nation-state societies to which the migrants have moved, however, frequently find these displays of concern and affection disconcerting. It is not simply that the migrants are failing to detach themselves from their old worlds-as social science wisdom and popular belief prescribe. In a world of mutually exclusive nation-states, rather, persons with foreign attachments are open to question, and all the more so when the relevant nation-states coexist on less than friendly terms.

Historically oriented scholars will remind us that there is no news here, 
though no one wants to fall into the trap of saying plus ça change, plus c'est la même chose. The problem is that the professional students of international migration and ethnicity have not broken with the everyday assumptions of the world in which they live, agreeing that the bounds of society and the nation-state normally converge. Conceptualizing the process as immigration - one in which people move for the purposes of settlement - they contend that attachments to the home left behind are imports that inevitably fade, as immigrants and their descendants gradually assimilate into a mainstream whose social ties are bounded at the water's edge.

To the students of immigrant transnationalism goes the great credit of seeing that connections between here and there are an inherent and enduring component of the long-distance migrations of the modern world. While implicitly rejecting the view that social relations should be contained within the boundaries of a state, however, the students of immigrant transnationalism have unfortunately forgotten about the processes that produce a container society-whether driven by states' efforts to bound the societies they enclose or by more informal, ethnocultural membership practices that aspire to the same goal. Therefore, the better view lies beyond the simplistic dichotomy of assimilation versus transnationalism, as these are not theories but rather social processes, inextricably intertwined. It is just such a perspective, emphasizing the regularity of international migration and its inevitable collision with the mechanisms by which nation-states attempt to keep themselves apart from the world, that we have tried to develop in these pages.

\section{REFERENCES}

Alba, Richard, and Victor Nee. 2003. Remaking the American Mainstream: Immigration and Contemporary Immigration. Cambridge, Mass.: Harvard University Press.

Amselle, Jean-Loup. 2002. "Globalization and the Future of Anthropology." African Affairs 101:212-29.

Anderson, Benedict. 1983. Imagined Communities: Reflections on the Origin and Spread of Nationalism. London: Verso.

- 1998. "Long-Distance Nationalism." Pp. 58-74 in The Spectre of Comparisons: Nationalism, Southeast Asia and the World, edited by Benedict Anderson. London: Verso.

Arendt, Hannah. (1951) 1996. The Age of Totalitarianism. New York: Harcourt.

Armstrong, John A. 1976. "Proletarian and Mobilized Diasporas." American Political Science Review 70 (2): 393-408.

Brubaker, Rogers. 1992. Citizenship and Nationhood in France and Germany. Cambridge, Mass.: Harvard University Press.

Florini, Ann M. 2000. The Rise of Transnational Civil Society. Washington, D.C.: Carnegie Endowment for International Peace.

Foner, Nancy. 2000. From Ellis Island to JFK: New York's Two Great Waves of Immigration. New Haven, Conn.: Yale University Press. 


\section{American Journal of Sociology}

Glick-Schiller, Nina. 1999. "Transmigrants and Nation-States: Something Old and Something New in the U.S. Immigrant Experience." Pp. 94-119 in The Handbook of International Migration: The American Experience, edited by Charles Hirschman, Philip Kasinitz, and Josh DeWind. New York: Russell Sage.

Glick-Schiller, Nina, Linda Basch, and Cristina Szanton-Blanc. 1992. Towards a Transnational Perspective on Migration: Race, Class, Ethnicity, and Nationalism Reconsidered. New York: New York Academy of Sciences.

- 1995. "From Immigrant to Transmigrant: Theorizing Transnational Migration. Anthropological Quarterly 68 (1): 48-63.

Glick-Schiller, Nina, and Georges Fouron. 1990. "Everywhere We Go, We Are in Danger: Ti Manno and the Emergence of a Haitian Transnational Identity." American Ethnologist 17 (2): 329-47.

Guarnizo, Luis E. 2001. "On the Political Participation of Transnational Migrants: Old Practices and New Trends.” Pp. 213-63 in E Pluribus Unum? Contemporary and Historical Perspectives on Immigrant Political Incorporation, edited by Gary Gerstle and John H. Mollenkopf. New York: Russell Sage.

Guarnizo, Luis, Alejandro Portes, and William J. Haller. 2003. "Assimilation and Transnationalism: Determinants of Transnational Political Action among Contemporary Migrants." American Journal of Sociology 108:1211-48.

Hobsbawm, Eric. 1994. The Age of Extremes: The Short Twentieth Century, 1914-1991. London: Michael Joseph.

Hockenos, Paul. 2003. Homeland Calling: Exile Patriotism and the Balkan Wars. Ithaca, N.Y.: Cornell University Press.

Huntington, Samuel P. 1997. "The Erosion of American National Interests." Foreign Affairs 76 (5): 28-49.

Joppke, Christian. 1998. Immigration and the Nation-State: The United States, Germany, and Great Britain. Oxford: Oxford University Press.

Karski, Jan. 1944. Story of a Secret State. Boston: Houghton-Mifflin.

Krasner, Stephen. 1995. "Power Politics, Institutions, and International Relations." Pp. 257-80 in Bringing Transnational Relations Back In, edited by Thomas RisseKappen. Cambridge: Cambridge University Press.

Levitt, Peggy. 2001a. The Transnational Villagers. Berkeley and Los Angeles: University of California Press.

. 2001b. "Transnational Migration: Taking Stock and Future Directions." Global Networks: A Journal of Transnational Affairs 1 (3): 195-216.

Morawska, Ewa. 2001. "Immigrants, Transnationalism, and Ethnicization: A Comparison of This Great Wave and the Last." Pp. 175-212 in E Pluribus Unum? Contemporary and Historical Perspectives on Immigrant Political Incorporation, edited by Gary Gerstle and John H. Mollenkopf. New York: Russell Sage.

Ostergaard-Nielsen, Eva. 2001a. "Diasporas in World Politics." In Non-state Actors in World Politics, edited by Daphne Josselin and William Wallace. New York: Palgrave. 2001b. "Transnational Political Practices and the Receiving State: Turks and Kurds in Germany and the Netherlands." Global Networks 1 (3): 261-82.

Portes, Alejandro. 1999. "Conclusion: Towards a New World-the Origins and Effects of Transnational Activities." Ethnic and Racial Studies 22 (2): 463-77.

- 2001. "Introduction: The Debates and Significance of Immigrant Transnationalism." Global Networks: A Journal of Transnational Affairs 1 (3): 181-94.

Portes, Alejandro, Luis E. Guarnizo, and Patricia Landolt. 1999. "The Study of Transnationalism: Pitfalls and Promise of an Emergent Research Field." Ethnic and Racial Studies 22 (2): 217-37.

Portes, Alejandro, William J. Haller, and Luis Eduardo Guarnizo. 2002. "Transnational Entrepreneurs: An Alternative Form of Immigrant Economic Adaptation." American Sociological Review 67 (2): 278-98. 


\section{Transnationalism in Question}

Rogers, Alasdair, Robin Cohen, and Steven Vertovec. 2001. "Editorial Statement." Global Networks: A Journal of Transnational Affairs 1 (1): 3-6.

Rouse, Roger. 1995. "Questions of Identity: Personhood and Collectivity in Transnational Migration to the United States." Critical Anthropology 15 (4): 351-80.

Sklair, Leslie. 2001. The Transnational Capitalist Class. Malden, Mass.: Blackwell.

Smith, Michael Peter, and Luis Eduardo Guarnizo. 1998. Transnationalism from Below. New Brunswick, N.J.: Transaction Publishers.

Smith, Robert C. 2002. "How Durable and New Is Transnational Life? Historical Retrieval through Local Comparison." Diaspora 9 (2): 203-34.

2003. "Diasporic Memberships in Historical Perspective: Comparative Insights from the Mexican, Italian and Polish Cases." International Migration Review 37 (3): $722-57$.

Smith, Tom W. 1994. What Do Americans Think about Jewes? New York: American Jewish Committee.

Stoller, Paul. 2002. Money Has No Smell: The Africanization of New York City. Chicago: University of Chicago Press.

UNHCR (United Nations High Commissioner for Refugees). 2000. State of the World's Refugees, 2000. New York: Oxford University Press.

Weiner, Myron. 1993. "Security, Stability and International Migration." Pp. 1-38 in International Migration and Security, edited by Myron Weiner. Boulder, Colo.: Westview.

Wimmer, Andreas, and Nina Glick-Schiller. 2002. "Methodological Nationalism and Beyond: Nation-State Building, Migration and the Social Sciences." Global Networks 2 (4): 301-34.

Zolberg, Aristide. 1999. "Matters of State: Theorizing Immigration Policy." Pp. 71-92 in The Handbook of International Migration: The American Experience, edited by Charles Hirschman, Philip Kasinitz, and Josh DeWind. New York: Russell Sage. 